\title{
Mitochondrial Localization of Human Recombinant Adenovirus: From Evolution to Gene Therapy
}

\author{
Salvatore Alesci ${ }^{a} \quad$ Mones Abu-Asab $^{b}$ Shiromi M. Perera ${ }^{d} \quad$ Maria Tsokos $^{b}$ \\ John C. Morris ${ }^{c}$ Karel Pacak ${ }^{d}$ \\ ${ }^{a}$ Clinical Neuroendocrinology Branch, National Institute of Mental Health, ${ }^{b}$ Laboratory of Pathology and \\ 'Metabolism Branch, Center for Cancer Research, National Cancer Institute, and ${ }^{\mathrm{d}}$ Reproductive Biology and \\ Medicine Branch, National Institute of Child Health and Human Development, National Institutes of Health, \\ Bethesda, Md., USA
}

\section{Key Words \\ Human recombinant adenovirus - Mitochondria • Recombinant viruses - Viral gene therapy}

\begin{abstract}
Mitochondrial research has influenced concepts in anthropology, human physiology and pathophysiology. We present here direct evidence that human recombinant viruses can localize in mitochondria to disrupt their integrity. This finding, while opening new perspectives in viral gene therapy, may provide new insights into the pathogenesis, prevention and treatment of viral diseases. In addition, it may advance the current understanding of cell evolution.
\end{abstract}

Copyright $\odot 2008$ S. Karger AG, Basel

This study was supported by the Intramural Research Programs of the National Institute of Mental Health, National Institute of Child Health and Human Development and National Cancer Institute at the National Institutes of Health.

\section{KARGER \\ Fax +41613061234 \\ E-Mail karger@karger.ch}

(C) 2008 S. Karger AG, Basel

www.karger.com
Accessible online at:

www.karger.com/nim
Viral diseases remain among the leading causes of death and disability worldwide. The emergence and reemergence of epidemic and pandemic viral outbreaks has posed for centuries a major challenge to human life. Furthermore, the new millennium faces the potential threat of deliberate use of deadly viruses as weapons for bioterrorism [1]. In contrast, recombinant adenoviral vectors $(\mathrm{rAd})$, genetically engineered from their wild-type relatives, have successfully been used to deliver foreign genes into a variety of cells and tissues for experimental and therapeutic purposes. Yet, there have also been warnings of significant toxicity associated with their administration [2].

We previously observed the appearance of atypical pleiomorphic mitochondria in bovine adrenal cortical cells infected with rAd [3]. In the present study we infected bovine adrenal chromaffin cells and a mouse pheochromocytoma cell line with Ad.null, a replicationdeficient $\mathrm{E}^{-} / \mathrm{E}^{-}{ }^{-} \mathrm{rAd}$ expressing no transgene. Ad.null was generated by calcium phosphate precipitation and homologous recombination (AdMax ${ }^{\circledR}$, Microbix Biosystems, Toronto, Ont., Canada), purified by double cesium chloride densitygradient centrifugation, titered as plaque-

\footnotetext{
Salvatore Alesci, MD, $\mathrm{PhD}$

Wyeth Research

500 Arcola Rd, Rm S-2323

Collegeville, PA 19426 (USA)

Tel. +1 484865 6263, Fax +1 484865 9402, E-Mail alescis@wyeth.com
} 

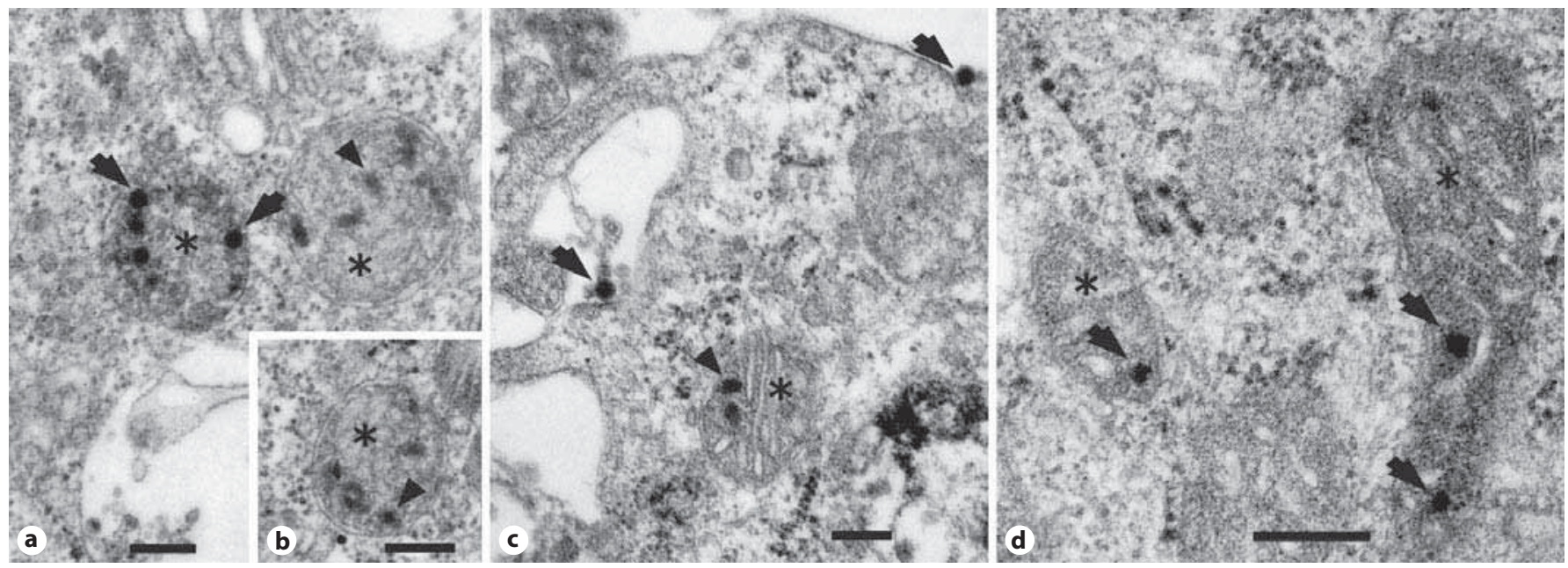

Fig. 1. Electron micrographs of bovine adrenal chromaffin cells $(\mathbf{a}-\mathbf{c})$ and mouse pheochromocytoma cells (d) infected with a recombinant non-replicating adenoviral vector. $\mathbf{a}, \mathbf{b}, \mathbf{d}$ Mitochondria at various stages of degeneration (asterisks) with deteriorated internal membrane and several adenoviral particles inside. c A mitochondrion with healthy internal structure and remnants of viral particles inside. Arrows = intact viral particles; arrowheads $=$ viral particles at various stages of breakdown. Bar $=500 \mathrm{~nm}$.

forming units $(\mathrm{PFU}) / \mathrm{ml}$ and stored at $-70^{\circ} \mathrm{C}$ in $10 \%$ glycerol-PBS. Bovine adrenal chromaffin cells and mouse pheochromocytoma cells, derived, cultured and maintained as described elsewhere $[4,5]$, were infected with 1,000 or $5,000 \mathrm{PFU} / \mathrm{cell}$ of Ad.null, for $90 \mathrm{~min}$ at $37^{\circ} \mathrm{C}$. After incubation, the cells were washed with PBS, fixed in $2.5 \%$ glutaraldehyde for $1 \mathrm{~h}$, and harvested by scraping and centrifugation at $2,500 \mathrm{rpm}$ for $10 \mathrm{~min}$. Cells were double-fixed in osmium tetroxide $(0.5 \%)$, dehydrated and embedded into Spurr's epoxy resin. Ultrathin sections $(90 \mathrm{~nm})$ were made, double-stained with uranyl acetate and lead citrate, and examined with a Philips CM10 transmission electron microscope (Electronic Instruments, Mahwah, N.J., USA).

Multiple distinct adenoviral particles were clearly visible inside mitochondria of infected cells when viewed with the electron microscope. The 'parasitized' organelles were in various stages of degeneration, from swelling to random spatial folding and fragmentation of the inner membrane, to complete loss of internal organization. Notably, disintegration of infected mitochondria was paralleled by breakdown of the viral capsid (fig. 1).

Mitochondria exert fundamental roles in intracellular energy production, intermediary metabolism and initiation of programmed cell death. Although these organelles possess a distinct self-replicating genome (mtDNA), the majority of their proteins are encoded by the nuclear
DNA. The interplay of the two genomes is critical in health and disease, and may have played a crucial role during evolution [6]. Inherited or acquired mtDNA disorders are complex, debilitating and often fatal [6]. Our findings suggest that the toxicity associated with adenoviral gene therapy may, at least in part, be related to the mitochondrial localization and consequent damage caused by rAd. At the same time, however, they indicate that, if appropriately engineered to maintain their mitochondrial tropism without disrupting this organelle, rAd might be effectively used for corrective gene therapies of mtDNA disorders. This study may also impact the current understanding of eukaryotic evolution. According to the 'endosymbiotic' hypothesis, modern mitochondria are the result of a mutualistic relationship between a primordial eukaryotic cell and a prokaryotic organism, followed by genetic redistribution and loss of redundant genes [6]. It remains obscure, however, how this genomic redistribution took place. The data presented here encourage the speculation that a primordial virus may have mediated or facilitated this genetic exchange; this ability may have been retained throughout evolution. Therefore, during infection, a virus may still be able to interfere with the normal cross-functionality of mtDNA and nDNA. Together with the structural and functional abnormalities caused by mitochondrial invasion, this intergenomic perturbation may be another important player in the 
damage associated with viral gene therapy and, by extension, in the pathophysiology of viral infections, viral carcinogenesis and escape from immune surveillance and antiviral drug resistance.
In times of growing concern about gene therapies, emerging viral diseases and biowarfare, we hope this study will put the captivating theme of virus-mitochondria interaction in the spotlight, fostering further investigation.

\section{References}

Mitochondrial Localization of Human Recombinant Adenovirus
1 Morens DM, Folkers GK, Fauci AS: The challenge of emerging and re-emerging infectious diseases. Nature 2004;430:242-249.

2 Marshall E: Gene therapy death prompts review of adenovirus vector. Science 1999;286: 2244-2245.

3 Alesci S, Ramsey WJ, Bornstein SR, Chrousos GP, Hornsby PJ, Benvenga S, Trimarchi F, Ehrhart-Bornstein M: Adenoviral vectors can impair adrenocortical steroidogenesis: Clinical implications for natural infections and gene therapy. Proc Natl Acad Sci USA 2002;99:7484-7489.
4 Ehrhart-Bornstein M, Haidan A, Alesci S, Bornstein SR: Neurotransmitters and neuropeptides in the differential regulation of steroidogenesis in adrenocortical-chromaffin co-cultures. Endocr Res 2000;26:833-842.

5 Powers JF, Evinger MJ, Tsokas P, Bedri S, Alroy J, Shahsavari M, Tischler AS: Pheochromocytoma cell lines from heterozygous neurofibromatosis knockout mice. Cell Tissue Res 2000;302:309-320.

6 Gray MW, Burger G, Lang BF: Mitochondrial evolution. Science 1999;283:1476-1481. 